\title{
Determination of the rate constant of hydroperoxyl radical reaction with phenol
}

\author{
Zsuzsanna Kozmér ${ }^{\mathrm{a}, \mathrm{b}, *}$, Eszter Arany ${ }^{\mathrm{a}}$, Tünde Alapi ${ }^{\mathrm{a}, \mathrm{c}}$, Erzsébet Takács ${ }^{\mathrm{b}}$, \\ László Wojnárovits ${ }^{\mathrm{b}}$, András Dombi ${ }^{\mathrm{a}}$ \\ ${ }^{a}$ Research Group of Environmental Chemistry, University of Szeged, H-6720 Szeged, Rerrich Béla tér 1, Hungary \\ b Department of Radiation Chemistry, Centre for Energy Research, Hungarian Academy of Sciences, H-1121 Budapest, \\ Konkoly-Thege Miklós út 29-33, Hungary \\ ${ }^{\mathrm{c}}$ Department of Inorganic and Analytical Chemistry, University of Szeged, H-6720 Szeged, Dóm tér 7, Hungary
}

\section{H I G H L I G H T S}

- Using formic acid and dissolved $\mathrm{O}_{2}$ almost all radicals are converted to $\mathrm{HO}_{2}^{\circ}$.

- Using sodium formate and dissolved $\mathrm{O}_{2}$ almost all radicals are converted to $\mathrm{O}_{2}^{*-}$.

- The $k_{\mathrm{HO}_{2}+\text { phenol }}$ was estimated to be $(2.7 \pm 1.2) \times 10^{3} \mathrm{~L} \mathrm{~mol}^{-1} \mathrm{~s}^{-1}$.

- $\mathrm{HO}_{2}^{*}$ is suggested to contribute significantly to the degradation of phenol.

\section{A R T I C L E I N F O}

\section{Article history:}

Received 2 September 2013

Accepted 21 April 2014

Available online 2 May 2014

Keywords:

Gamma radiolysis

Formic acid

Sodium formate

Radical transfer

Superoxide radical ion

$\mathrm{pH}$

\begin{abstract}
A B S T R A C T
The rate constant of $\mathrm{HO}_{2}^{*}$ reaction with phenol $\left(k_{\mathrm{HO}_{2}+\text { phenol }}\right)$ was investigated. The primary radical set produced in water $\gamma$ radiolysis $\left({ }^{\circ} \mathrm{OH}, \mathrm{e}_{\mathrm{aq}}^{-}\right.$and $\mathrm{H}^{*}$ ) was transformed to $\mathrm{HO}_{2}^{\cdot} / \mathrm{O}_{2}^{\cdot-}$ by using dissolved oxygen and formate anion (in the form of either formic acid or sodium formate). The concentration ratio of $\mathrm{HO}_{2}^{*} / \mathrm{O}_{2}^{-}$- was affected by the $\mathrm{pH}$ value of the solution: under acidic conditions (using $\mathrm{HCOOH}$ ) almost all radicals were converted to $\mathrm{HO}_{2}^{+}$, while under alkaline conditions (using $\mathrm{HCOONa}$ ) to $\mathrm{O}_{2}^{-}{ }^{-}$. The degradation rate of phenol was significantly higher using $\mathrm{HCOOH}$. From the ratio of reaction rates under the two reaction conditions $k_{\mathrm{HO}_{2}}+$ phenol was estimated to be $(2.7 \pm 1.2) \times 10^{3} \mathrm{~L} \mathrm{~mol}^{-1} \mathrm{~s}^{-1}$.
\end{abstract}

(c) 2014 Elsevier Ltd. All rights reserved.

\section{Introduction}

In the last two decades a large number of papers were published on advanced oxidation processes (AOPs), these methods could complete the traditional water purifying technologies. Using these methods, the mineralization of the target compounds takes place in reactions with reactive free radicals (hydroxyl radical $\left({ }^{\circ} \mathrm{OH}\right)$, hydrogen atom/hydrated electron $\left({ }^{\bullet} \mathrm{H} / \mathrm{e}_{\mathrm{aq}}^{-}\right)$, hydroperoxyl radical/superoxide radical anion $\left(\mathrm{HO}_{2}^{*} / \mathrm{O}_{2}^{-}\right)$, etc.).

\footnotetext{
* Corresponding author at: Research Group of Environmental Chemistry, University of Szeged, H-6720 Szeged, Rerrich Béla tér 1, Hungary. Tel.: + 366254 4719; fax: + 3662544338

E-mail addresses: kozmerzs@chem.u-szeged.hu (Z. Kozmér), arany.eszter@chem.u-szeged.hu (E. Arany), alapi@chem.u-szeged.hu (T. Alapi), erzsebet.takacs@energia.mta.hu (E. Takács),

wojnarovits.laszlo@energia.mta.hu (L. Wojnárovits), dombia@chem.u-szeged.hu (A. Dombi).
}

For the optimization of the degradation pathways accurate knowledge of mechanisms, for example the contribution of the less investigated, low reactivity radicals is needed. Unfortunately, reaction rate values of $\mathrm{HO}_{2}^{*} / \mathrm{O}_{2}^{-}$are usually reported only for quinone-type compounds or for aromatics compounds at high temperature (e.g. $k_{\mathrm{HO}_{2}}+$ toluene $=(5.5 \pm 1.5) \times 10^{4} \mathrm{~L} \mathrm{~mol}^{-1} \mathrm{~s}^{-1}$ ) (Scott and Walker, 2002) and their reaction mechanisms are very diverse (Bielski et al., 1985). Tsujimoto et al. (1993) published a study about the determination of the second-order rate constants of the reaction between $\mathrm{O}_{2}^{--}$and various dental phenolic compounds (e.g. phenol) by electron spin resonance spin-trapping technique. In that study the $\mathrm{O}_{2}^{--}$was generated by the HPX-XOD (hypoxanthin-xanthin oxidase) reaction system and it was detected as spin adduct (DMPO- $\mathrm{O}_{2}^{--}$) of spin-trap agent, 5,5dimethyl-1-pyrroline-N oxide (DMPO) by ESR spectrometry. The amount of DMPO- $\mathrm{O}_{2}^{-}$- adduct decreased due to the reaction with phenolic compounds. The rate constants of reaction between $\mathrm{O}_{2}^{-}$ and phenolic compounds were calculated by the method of kinetic competition with $50 \%$ inhibitory dosage of phenolic additives. 
Our study was aimed at the investigation of the reaction of $\mathrm{HO}_{2}^{*} / \mathrm{O}_{2}^{-}$- with a simple model compound, phenol and at the determination of the $\mathrm{HO}_{2}^{-}$+ phenol reaction rate constant, since there is no information about it in the literature.

For the method of Tsujimoto et al. (1993) the detection of $\mathrm{O}_{2}^{--}$-adduct was needed; however in case of $\mathrm{HO}_{2}^{*}$ there is no simply detectable product from the reaction with phenol. Thus another method was found to investigate the reaction between phenol and $\mathrm{HO}_{2}^{-}$. In our work a mediate method was used for the determination. The reactive intermediates were produced by the $\gamma$-radiolysis of water in dilute phenol solution and the degradation rate of $\mathrm{HO}_{2}^{*}+$ phenol reaction was utilized for the calculation of rate constant.

During irradiation of water with ionizing radiation ${ }^{\circ} \mathrm{OH}, \mathrm{e}_{\mathrm{aq}}^{-}$and $\mathrm{H}^{*}$ form as reactive radical intermediates (1). In dilute aqueous solution they may react with solute molecules with $G$ values of $0.28,0.28$ and $0.062 \mu \mathrm{mol} \mathrm{J}^{-1}$ (Buxton, 2004; Spinks and Woods, 1990).

$\mathrm{H}_{2} \mathrm{O}+\gamma \rightarrow{ }^{\bullet} \mathrm{OH}, \mathrm{e}_{\mathrm{aq}}^{-}, \mathrm{H}^{\bullet}$

The latter two species are conjugate acid-base pairs (2) with a formal $\mathrm{p} K_{\mathrm{a}}$ of 9.6 (Buxton, 2004):

$\mathrm{H}^{\bullet}+\mathrm{H}_{2} \mathrm{O} \rightleftharpoons \mathrm{e}_{\mathrm{aq}}^{-}+\mathrm{H}_{3} \mathrm{O}^{+} \quad \mathrm{p} K_{\mathrm{a}}=9.6$

The forward reaction is very slow, $k_{2}=19 \mathrm{~L} \mathrm{~mol}^{-1} \mathrm{~s}^{-1}$ (Buxton, 2004), while the reversed reaction is very fast, $k_{-2}=2.3 \times$ $10^{10} \mathrm{~L} \mathrm{~mol}^{-1} \mathrm{~s}^{-1}$ therefore below $\mathrm{pH} \mathrm{3}$, under the usual experimental conditions $\mathrm{e}_{\mathrm{aq}}^{-}$conversion to $\mathrm{H}^{\cdot}$ is practically complete (Hartig and Getoff, 1982).

These reactive intermediates react with phenol according to Eqs. (3)-(5) forming dihydroxy cyclohexadienyl radicals and hydroxy cyclohexadienyl radicals:<smiles>Oc1ccccc1COc1ccccc1</smiles>

(Bonin et al., 2007)<smiles>Oc1ccccc1C=C1CCCCC1</smiles>

$$
k_{4}=1.7 \times 10^{9} \mathrm{~L} \mathrm{~mol}^{-1} \mathrm{~s}^{-1}
$$

(Buxton et al., 1988)

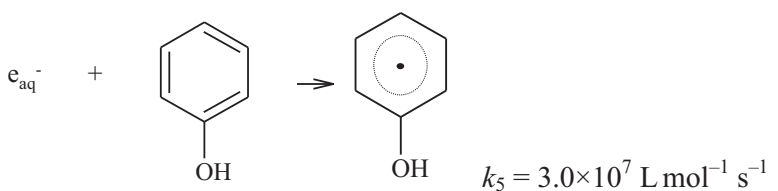

(Lai and Freeman, 1990)

Dissolved $\mathrm{O}_{2}$ molecule reacts with $\mathrm{H}^{*} / \mathrm{e}_{\mathrm{aq}}^{-}$and transforms these intermediates to $\mathrm{HO}_{2}^{*} / \mathrm{O}_{2}^{--}(6)-(8)$.

$\mathrm{H}^{\bullet}+\mathrm{O}_{2} \rightarrow \mathrm{HO}_{2}^{\cdot} \quad k_{6}=2.1 \times 10^{10} \mathrm{~L} \mathrm{~mol}^{-1} \mathrm{~s}^{-1}$

(Buxton et al., 1988)

$\mathrm{e}_{\mathrm{aq}}^{-}+\mathrm{O}_{2} \rightarrow \mathrm{O}_{2}^{\cdot-} \quad k_{7}=1.9 \times 10^{10} \mathrm{~L} \mathrm{~mol}^{-1} \mathrm{~s}^{-1}$
(Buxton et al., 1988)

$\mathrm{HO}_{2}^{\circ} \rightleftharpoons \mathrm{H}^{+}+\mathrm{O}_{2}^{--} \quad \mathrm{p} K_{\mathrm{a}}=4.8$

(Bielski et al., 1985)

The effect of $\mathrm{HO}_{2}^{-} / \mathrm{O}_{2}^{-}$during the degradation processes is usually neglected, since they are considered to be low reactivity radicals. The rate constant of the reaction between phenol and $\mathrm{O}_{2}^{--}$(9) reported in the literature (Tsujimoto et al., 1993) supports this view.

$\mathrm{O}_{2}^{\cdot-}+$ products

(Tsujimoto et al., 1993)

Our measurements were carried out in oxygen saturated formic acid/sodium formate containing solution in order to transform ' $\mathrm{OH}$ to $\mathrm{HO}_{2}^{*} / \mathrm{O}_{2}^{\cdot-}$ in the reactions (10)-(13).

$\mathrm{HCOOH}+{ }^{\cdot} \mathrm{OH} \rightarrow{ }^{\cdot} \mathrm{COOH}+\mathrm{H}_{2} \mathrm{O} \quad k_{10}=1.3 \times 10^{8} \mathrm{~L} \mathrm{~mol}^{-1} \mathrm{~s}^{-1}$

(Bielski et al., 1985)

$\mathrm{HCOO}^{-}+{ }^{\cdot} \mathrm{OH} \rightarrow \mathrm{CO}_{2}^{--}+\mathrm{H}_{2} \mathrm{O} \quad k_{11}=3.2 \times 10^{9} \mathrm{~L} \mathrm{~mol}^{-1} \mathrm{~s}^{-1}$

(Bielski et al., 1985)

$\cdot \mathrm{COOH}+\mathrm{O}_{2} \rightarrow \mathrm{HO}_{2}^{\cdot}+\mathrm{CO}_{2} \quad k_{12}=3 \times 10^{9} \mathrm{~L} \mathrm{~mol}^{-1} \mathrm{~s}^{-1}$

(Leitner and Dore, 1996)

$\mathrm{CO}_{2}^{--}+\mathrm{O}_{2} \rightarrow \mathrm{O}_{2}^{--}+\mathrm{CO}_{2} \quad k_{13}=4.2 \times 10^{9} \mathrm{~L} \mathrm{~mol}^{-1} \mathrm{~s}^{-1}$

(Ilan and Rabani, 1976)

The two carbon centered species $\left({ }^{\circ} \mathrm{COOH} / \mathrm{CO}_{2}^{--}\right)$are conjugate acid-base pairs (14) with a formal $\mathrm{p} K_{\mathrm{a}}$ of 1.4 (Leitner and Dore, 1996):

$\cdot \mathrm{COOH} \rightleftharpoons \mathrm{H}^{+}+\mathrm{CO}_{2}^{--} \quad \mathrm{p} K_{\mathrm{a}}=1.4$

In conclusion, in the presence of both $\mathrm{O}_{2}$ and formic acid or formate ions all of the primary reactive species transform to $\mathrm{HO}_{2}^{\circ} / \mathrm{O}_{2}^{--}$, giving an outstanding possibility for studying the reactions of these intermediates.

In regard to the $\mathrm{p} K_{\mathrm{a}}$ value of $\mathrm{HO}_{2}^{*} / \mathrm{O}_{2}^{--}$(4.8) (Bielski et al., 1985), the ratio of the concentration of $\mathrm{HO}_{2}^{\circ} / \mathrm{O}_{2}^{-}{ }^{-}$could be affected by the $\mathrm{pH}$ of the solution. Using low $\mathrm{pH}$ (for example in the presence of $\mathrm{HCOOH}$ in great excess) $\mathrm{HO}_{2}^{-}$will dominate, while at higher $\mathrm{pH}$ (neutral or alkaline, using $\mathrm{HCOONa}$ in great excess) $\mathrm{O}_{2}^{--}$will be the dominating reactive intermediate.

\section{Experimental}

\subsection{Materials}

During our experiments with a ${ }^{60}$ Co source $250 \mathrm{~mL} 1.0 \times$ $10^{-4} \mathrm{~mol} \mathrm{~L}^{-1}\left(c_{0}\right)$ aqueous phenol (Sigma-Aldrich, $\geq 99 \%$ ) solutions were irradiated in the presence of $0.50 \mathrm{~mol} \mathrm{~L}^{-1}$ formic acid (AnalR NormaPUR, 99-100\%) or $0.05 \mathrm{~mol} \mathrm{~L}^{-1}$ sodium formate (FLUKA, 99.0\%) prepared in ultrapure MILLI-Q water (ELGA option 4).

\subsection{Experimental setup}

The $250 \mathrm{~mL}$ reservoir was placed near an SSL-01 panoramic type ${ }^{60} \mathrm{Co}-\gamma$ source to have a dose rate of $1.5 \mathrm{kG} \mathrm{y} \mathrm{h}^{-1}$. Since the yield of the primary radicals is $0.28+0.28+0.062=0.622 \mu \mathrm{mol} \mathrm{J}^{-1}$ (Spinks and Woods, 1990) and the density of diluted aqueous 
solutions is $\sim 1 \mathrm{~kg} \mathrm{~L}^{-1}$, the rate of radical formation was calculated to be $1500 / 3600 \mathrm{~J} \mathrm{~kg}^{-1} \mathrm{~s}^{-1} \times 1 \mathrm{~kg} \mathrm{~L}^{-1} \times 0.622 \times 10^{-6} \mathrm{~mol} \mathrm{~J}^{-1}=$ $2.6 \times 10^{-7} \mathrm{~mol} \mathrm{~L}^{-1} \mathrm{~s}^{-1}$. The solutions were purged with oxygen gas ( $>99.5 \%$ purity) $\left(c_{\mathrm{O}_{2}}=12.5 \times 10^{-4} \mathrm{~mol} \mathrm{~L}^{-1}\right)$ before the reaction for $20 \mathrm{~min}$ and throughout the irradiation. The reservoir was thermostated $\left(25.0 \pm 0.5^{\circ} \mathrm{C}\right)$ and the solution was continuously mixed by $\mathrm{O}_{2}$ bubbling. Kinetic investigations were started by lifting up the $\gamma$ source in the irradiation chamber. Samples were taken from the reservoir at different time intervals. Two parallel measurements were performed in the case of each reaction condition. During the degradation processes the $\mathrm{pH}$ of the solution usually changed, thus, the $\mathrm{pH}$ of each sample was measured with a METTLER TOLEDO MP225 type pH meter.

\subsection{High performance liquid chromatography (HPLC)}

The degradation of phenol was followed by an Agilent 1100 Series HPLC equipment with UV detection using a reverse phase LiChroCART ${ }^{\circledR} 150-4.6$, RP-18 column with $5 \mu \mathrm{m}$ particle size. The mobile phase consisted of 35\% methanol (VWR, 99.80\%) and 65\% ultrapure MILLI-Q water (MILLIPORE Milli-Q Direct 8/16). During separation $20 \mu \mathrm{L}$ sample was analyzed using an eluent flow rate of $0.80 \mathrm{~mL} \mathrm{~min}^{-1}$ at $25{ }^{\circ} \mathrm{C}$ and detection wavelength of $210 \mathrm{~nm}$.

\section{Results and discussion}

In this research the effect of formic acid/formate ions on phenol degradation was investigated at low $\mathrm{pH}$ (using $\mathrm{HCOOH}$ ) and at high $\mathrm{pH}$ (using $\mathrm{HCOONa}$ ) during the $\gamma$ radiolysis of oxygenated phenol solutions. In case of using $\mathrm{HCOOH}$ the $\mathrm{pH}$ of the solution was low, 2.09, and it did not change with the irradiation. In case of HCOONa there was some change in the $\mathrm{pH}$ during irradiation, the average $\mathrm{pH}$ at low conversion was around 7.88. As it can be seen in Fig. 1, the transformation rate of phenol was significantly higher under acidic conditions (using $\mathrm{HCOOH}$ ) than in slightly alkaline media (using HCOONa).

The degradation rates of reactions were determined from the slopes of the linear trendlines fitted to the initial values (to 5\% phenol conversion). The ratio of the degradation rates was calculated as follows (15):

$\frac{r_{\mathrm{HO}_{2}^{-}+\text {phenol }}}{r_{\mathrm{O}_{2}^{-}}+\text {phenol }}=\frac{4.3 \times 10^{-6} \mathrm{~mol} \mathrm{~L}^{-1} \mathrm{kG} \mathrm{y}^{-1}}{3.3 \times 10^{-6} \mathrm{~mol} \mathrm{~L}^{-1} \mathrm{kG} \mathrm{y}^{-1}}=1.3$

Since the $c_{\mathrm{O}_{2}}\left(12.5 \times 10^{-4} \mathrm{~mol} \mathrm{~L}^{-1}\right)$ was more than one order of magnitude higher than the concentration of phenol, $c_{0}$ $\left(1.0 \times 10^{-4} \mathrm{~mol} \mathrm{~L}^{-1}\right)$ and also $k_{6}$ and $k_{7}$ were with $1-3$ orders of magnitude higher than $k_{4}$ and $k_{5}$, practically all $\mathrm{H}^{*} / \mathrm{e}_{\mathrm{aq}}^{-}$were converted to $\mathrm{HO}_{2}^{*} / \mathrm{O}_{2}^{-}$. At the beginning of the reactions the actual concentrations of the solutes ([phenol], [HCOOH] and $\left.\left[\mathrm{HCOO}^{-}\right]\right)$can be considered roughly equal to their initial concentrations $\left(1.0 \times 10^{-4}, 0.50\right.$ and $0.05 \mathrm{~mol} \mathrm{~L}^{-1}$, respectively). Using these concentrations ${ }^{\circ} \mathrm{OH}$ reacted with the formic acid or formate ion additives with reaction rates approx. 2 orders of magnitude higher than with phenol. Therefore, under our conditions ${ }^{\circ} \mathrm{OH}$ was also practically entirely converted to $\mathrm{HO}_{2}^{\circ} / \mathrm{O}_{2}^{-}$and the effect of these reactive species to the degradation rate of phenol could be investigated.

Using the dissociation constant of $\mathrm{HO}_{2}^{-} \quad\left(K_{\mathrm{HO}_{2}^{*}}=1.6 \times\right.$ $10^{-5} \mathrm{~mol} \mathrm{~L}^{-1}$ ) (Bielski et al., 1985) the $\mathrm{HO}_{2}^{-}$and $\mathrm{O}_{2}^{--}$concentrations were calculated by the following relations:

$\left[\mathrm{HO}_{2}^{*}\right]=\frac{\left[\mathrm{H}^{+}\right]}{K_{\mathrm{HO}_{2}^{+}}}\left[\mathrm{O}_{2}^{--}\right], \quad\left[\mathrm{O}_{2}^{--}\right]=\frac{K_{\mathrm{HO}_{2}^{*}}}{\left[\mathrm{H}^{+}\right]}\left[\mathrm{HO}_{2}^{*}\right]$

Under our conditions at low $\mathrm{pH}$ the $\mathrm{HO}_{2}^{\circ} / \mathrm{O}_{2}^{-}$- pair was present nearly exclusively in the $\mathrm{HO}_{2}^{-}$form, while at the higher $\mathrm{pH}$ practically entirely in the $\mathrm{O}_{2}^{--}$form.

The $\mathrm{HO}_{2}^{*} / \mathrm{O}_{2}^{-}$radicals either react with phenol or they disappear in self-termination reactions (17)-(19).

$2 \mathrm{HO}_{2}^{\circ} \rightarrow \mathrm{H}_{2} \mathrm{O}_{2}+\mathrm{O}_{2} \quad k_{\mathrm{HO}_{2}^{*}+\mathrm{HO}_{2}^{*}}=8.3 \times 10^{5} \mathrm{~L} \mathrm{~mol}^{-1} \mathrm{~s}^{-1}$

(Bielski et al., 1985)

$\mathrm{HO}_{2}^{-}+\mathrm{O}_{2}^{--}+\mathrm{H}_{2} \mathrm{O} \rightarrow \mathrm{H}_{2} \mathrm{O}_{2}+\mathrm{O}_{2}+\mathrm{OH}^{-}$

$k_{\mathrm{HO}_{2}^{-}+\mathrm{O}_{2}^{--}}=9.7 \times 10^{7} \mathrm{~L} \mathrm{~mol}^{-1} \mathrm{~s}^{-1}$

(Bielski et al., 1985)

$$
\begin{gathered}
2 \mathrm{O}_{2}{ }^{--}+\mathrm{H}_{2} \mathrm{O} \rightarrow \mathrm{H}_{2} \mathrm{O}_{2}+\mathrm{O}_{2}+2 \mathrm{OH}^{-} \\
k_{19}<3 \times 10^{-1} \mathrm{~L} \mathrm{~mol}^{-1} \mathrm{~s}^{-1}
\end{gathered}
$$

(Bielski et al., 1985)

Since the rate of radical formation, $2.6 \times 10^{-7} \mathrm{~mol} \mathrm{~L}^{-1} \mathrm{~s}^{-1}$, was much higher than the rate of phenol degradation, $1.8 \times$ $10^{-9} \mathrm{~mol} \mathrm{~L}^{-1} \mathrm{~s}^{-1}$ and $1.4 \times 10^{-9} \mathrm{~mol} \mathrm{~L}^{-1} \mathrm{~s}^{-1}$, the $\mathrm{HO}_{2}^{\circ} / \mathrm{O}_{2}^{-}$radicals mainly decayed in self-termination reactions. In other words it was assumed that the presence of phenol did not influence much the steady state concentrations of $\mathrm{HO}_{2}^{+}$and $\mathrm{O}_{2}^{-}$.

Using the steady state approximation for the concentration of the radicals, the rate of radical formation is equal to the rate of radical recombination. The recombination of the peroxyl type radicals $\left(\mathrm{HO}_{2}^{*} / \mathrm{O}_{2}^{--}\right)$depends strongly on the $\mathrm{pH}$ (Bielski et al., 1985), therefore in case of $\mathrm{HCOOH}$ (due to the low $\mathrm{pH}$ value $(\sim 2.0)$ ) the recombination of two $\mathrm{HO}_{2}^{*}(17)$ and the reaction

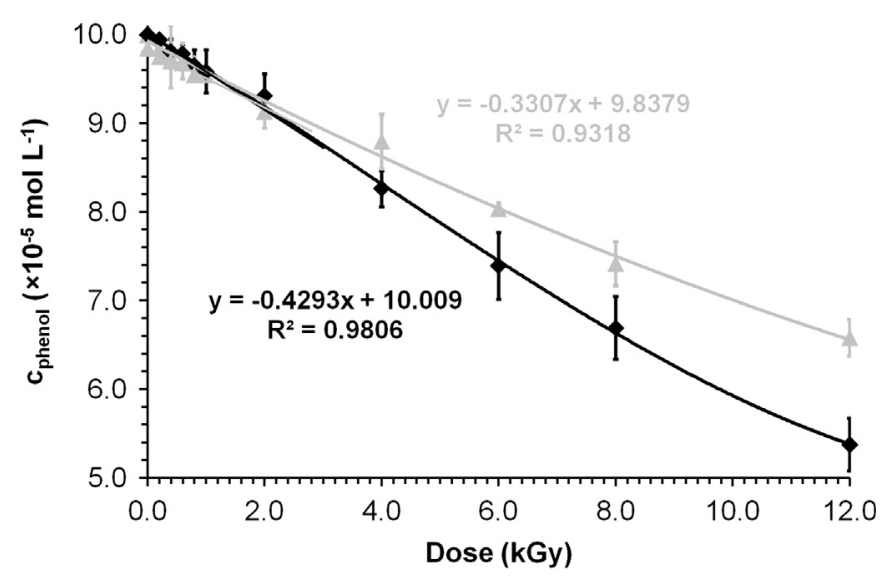

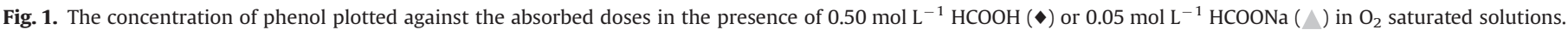
The error bars show the standard deviation of the measured points. The equations show the slopes of linear trendlines fitted to the initial values. 
between $\mathrm{HO}_{2}^{-}$and $\mathrm{O}_{2}^{--}$(18) should be taken into account. In case of HCOONa (due to the high $\mathrm{pH}$ value $(>7.0)$ ) only the reaction between $\mathrm{HO}_{2}^{-}$and $\mathrm{O}_{2}^{--}$(18) should be considered. The reaction between two $\mathrm{O}_{2}^{-}(19)$ is negligible even at extremely high $\mathrm{pH}$ (Bielski et al., 1985), therefore this reaction has no influence neither at low nor at high $\mathrm{pH}$.

At low $\mathrm{pH}$ (2.09) using $\mathrm{HCOOH}$ one may write the following:

$r_{\mathrm{HO}_{2}}$ formation

$$
\begin{aligned}
& =r_{\mathrm{HO}_{2}^{-}}+\mathrm{HO}_{2}^{+}+r_{\mathrm{HO}_{2}^{*}+\mathrm{O}_{2}^{-}}
\end{aligned}
$$

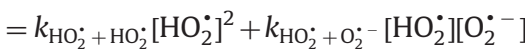

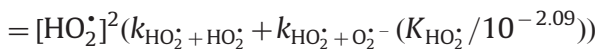

At higher $\mathrm{pH}$ (7.88) using HCOONa the following equation describes recombination (21):

$$
\begin{aligned}
r_{\mathrm{O}_{2}^{--}} \text {formation } & =r_{\mathrm{HO}_{2}^{+}+\mathrm{O}_{2}^{--}} \\
& =k_{\mathrm{HO}_{2}^{-}+\mathrm{O}_{2}^{--}}\left[\mathrm{HO}_{2}^{-}\right]\left[\mathrm{O}_{2}^{-{ }^{-}}\right] \\
& =k_{\mathrm{HO}_{2}+\mathrm{O}_{2}^{-}}\left[\mathrm{O}_{2}^{--}\right]^{2} \frac{10^{-7.88}}{K_{\mathrm{HO}_{2}^{-}}}
\end{aligned}
$$

Since all radicals were converted to $\mathrm{HO}_{2}^{*}$ using $\mathrm{HCOOH}$ and to $\mathrm{O}_{2}^{--}$using HCOONa, it might be assumed that $r_{\mathrm{HO}_{2} \text { formation }}=$ $r_{\mathrm{O}_{2}^{-}-}$formation. Therefore, using Eqs. (20) and (21) the $\left[\mathrm{O}_{2}^{-{ }^{-}}\right]^{\mathrm{pH}=7.88}$ / $\left[\mathrm{HO}_{2}^{\circ}\right]^{\mathrm{pH}=2.09}$ ratio could be calculated (22):

$$
\begin{aligned}
& \frac{\left[\mathrm{O}_{2}^{\cdot-}\right]^{\mathrm{pH}=7.88}}{\left[\mathrm{HO}_{2}^{\circ}\right]^{\mathrm{pH}=2.09}}
\end{aligned}
$$

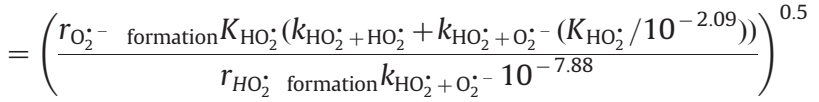

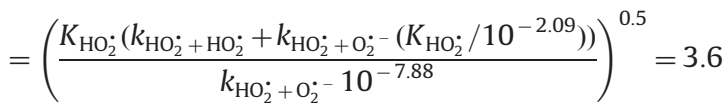

The adequate rate equations that describe the reaction of $\mathrm{HO}_{2}^{*}$ and $\mathrm{O}_{2}^{-}$- with phenol can be given as

$$
\begin{aligned}
& \mathrm{HCOOH}: r_{\mathrm{HO}_{2}+\text { phenol }}=k_{\mathrm{HO}_{2}}{ }^{*}+\text { phenol }\left[\mathrm{HO}_{2}{ }^{\bullet}\right]^{p H}=2.09[\text { phenol }] \\
& \text { HCOONa : } r_{\mathrm{O}_{2}^{--}+\text {phenol }}=k_{\mathrm{O}_{2}^{-}+\text {phenol }}\left[\mathrm{O}_{2}^{\cdot-}\right]^{p H=7.88}[\text { phenol }]
\end{aligned}
$$

On the basis of the ratio of Eqs. (23) and (24), knowing the values of $r_{\mathrm{HO}_{2}+\text { phenol }} / r_{\mathrm{O}_{2}^{-}}+$phenol and $\left[\mathrm{O}_{2}^{-{ }^{-}}\right]^{\mathrm{pH}=7.88} /\left[\mathrm{HO}_{2}^{*}\right]^{\mathrm{pH}=2.09}$ the $k_{\mathrm{HO}_{2}+\text { phenol }} / k_{\mathrm{O}_{2}^{-}}+$phenol ratio could be determined (25):

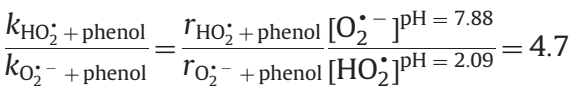

Using the former ratio and the value of $k_{\mathrm{O}_{2}^{-}}{ }^{-}+$phenol from the literature $\left(5.8 \times 10^{2} \mathrm{~L} \mathrm{~mol}^{-1} \mathrm{~s}^{-1}\right)$ (Tsujimoto et al., 1993) the
$k_{\mathrm{HO}_{2}}+$ phenol could be estimated (26):

$k_{\mathrm{HO}_{2}}+$ phenol $=4.7 \times k_{\mathrm{O}_{2}^{-}}+$phenol $=(2.7 \pm 1.2) \times 10^{3} \mathrm{~L} \mathrm{~mol}^{-1} \mathrm{~s}^{-1}$

\section{Conclusions}

The rate constant of reaction between phenol and $\mathrm{HO}_{2}^{*}$ was estimated to be $(2.7 \pm 1.2) \times 10^{3} \mathrm{~L} \mathrm{~mol}^{-1} \mathrm{~s}^{-1}$. This value is in agreement with the assumption that $\mathrm{HO}_{2}^{*}$ reacts more effectively with phenol than $\mathrm{O}_{2}^{--}$. Because in the lower $\mathrm{pH}$ range the rate of self-termination is also relatively low, $\mathrm{HO}_{2}^{*}$ might significantly contribute to the degradation processes of phenol. On the other hand the contribution of $\mathrm{O}_{2}^{-}$to the degradation of phenol seems to be negligible because of its low reactivity.

\section{Acknowledgments}

The financial support of the Hungarian Research Foundation (NK 105802) and the Swiss Contribution (SH7/2/20) is highly appreciated. This research was supported by the European Union and the State of Hungary, co-financed by the European Social Fund in the framework of TÁMOP-4.2.4.A/ 2-11/1-2012-0001 'National Excellence Program'.

\section{References}

Bielski, B.H.J., Cabelli, D.E., Arudi, R.L., Ross, A.B., 1985. Reactivity of $\mathrm{HO}_{2} / \mathrm{O}_{2}^{-}$radicals in aqueous-solution. J. Phys. Chem. Ref. Data 14, 1041-1100.

Bonin, J., Janik, I., Janik, D., Bartels, D.M., 2007. Reaction of the hydroxyl radical with phenol in water up to supercritical conditions. J. Phys. Chem. A 111, 1869-1878.

Buxton, G.V., 2004. The radiation chemistry of liquid water: principles and applications. In: Mozumder, A., Hatano, Y., Dekker, M. (Eds.), Charged Particle and Photon Interaction with Matter, pp. 331-363.

Buxton, G.V., Greenstock, C.L., Helman, W.P., Ross, A.B., 1988. Critical review of rate constants for reactions of hydrated electrons, hydrogen atoms and hydroxyl radicals $\left({ }^{\circ} \mathrm{OH} /{ }^{\circ} \mathrm{O}^{-}\right)$in aqueous solution. J. Phys. Chem. Ref. Data $17,513-886$.

Hartig, K.J., Getoff, N., 1982. Reactivity of hydrogen atoms with liquid water. J. Photochem. 18, 29-38.

Ilan, Y., Rabani, J., 1976. On some fundamental reactions in radiation chemistry: nanosecond pulse radiolysis. Int. J. Radiat. Phys. Chem. 8, 609-611.

Lai, C.C., Freeman, G.R., 1990. Solvent effects on the reactivity of solvated electron with organic solutes in methanol water and ethanol water mixed-solvents. J. Phys. Chem. 94, 302-308.

Leitner, N.K.V., Dore, M., 1996. Hydroxyl radical induced decomposition of aliphatic acids in oxygenated and deoxygenated aqueous solutions. J. Photochem. Photobiol. A 99, 137-143.

Scott, M., Walker, R.W., 2002. Addition of toluene and ethylbenzene to mixtures of $\mathrm{H}_{2}$ and $\mathrm{O}_{2}$ at $773 \mathrm{~K}$ : Part I: kinetic measurements for $\mathrm{H}$ and $\mathrm{HO}_{2}$ reactions with the additives and a data base for $\mathrm{H}$ abstraction by $\mathrm{HO}_{2}$ from alkanes, aromatics and related compounds. Combust. Flame 129, 365-377.

Spinks, J.W.T., Woods, R.J., 1990. An Introduction to Radiation Chemistry, 3rd ed. Wiley-Interscience, New York, USA.

Tsujimoto, Y., Hashizume, H., Yamazaki, M., 1993. Superoxide radical scavenging activity of phenolic compounds. Int. J. Biochem. 25, 491-494. 